\title{
Taxonomy, morphology and distribution of the Sellaphora stroemii complex (Bacillariophyceae)
}

\author{
Elisa Falasco ${ }^{1,2}$, Saúl Blanco ${ }^{1,3}$, Francesca BonA ${ }^{2}$, Joan Gomì ${ }^{1,4}$, Daša HlúBIKovÁ ${ }^{1}$, \\ Maria Helena Novais ${ }^{1,5}$, Lucien HoffmanN ${ }^{1}$ \& Luc Ector ${ }^{1}$
}

${ }^{1}$ Department of Environment and Agro-biotechnologies (EVA), Public Research Centre - Gabriel Lippmann, Rue du Brill 41,L-4422 Belvaux, Luxembourg; e-mail: ector@lippmann.lu

${ }^{2}$ DBAU, University of Turin, via Accademia Albertina 13, I-10123 Turin, Italy; corresponding author e-mail: elisa.falasco@unito.it

${ }^{3}$ Área de Ecología, Universidad de León, E-24071 León, Spain

${ }^{4}$ Departament d'Ecologia, Universitat de Barcelona, Av. Diagonal 645, E-08028 Barcelona, Spain

${ }^{5}$ Laboratório da Água, Instituto de Ciências Agrárias Mediterrânicas, Universidade de Évora, Parque Industrial e Tecnológico, Rua da Barba Rala $n^{\circ}$ 1, P-7005-345 Évora, Portugal

\begin{abstract}
Live and treated materials from three populations of diatoms collected in Italy, Slovakia and Spain, identified in previous inventories as Navicula stroemii Hust. sensu KRAMmer et LANGE-Bertalot, were examined under light and scanning electron microscopy. The analyses highlighted the typical single H-shaped plastid, characteristic of the genus Sellaphora. Considering this, we thoroughly investigated type materials from the Sellaphora stroemii complex. According to the standard European diatom flora of KRAMmER \& LANGE-BERTALOT (1986: Süßwasserflora von Mitteleuropa 2/1), six species should be considered as taxonomic synonyms of Navicula stroemii, now Sellaphora stroemii (Hust.) H. Kobayasi in Mayama et al.: Navicula aggerica E. ReIChARDT, $N$. rivularis Hust., N. subbacillum Hust., N. subcontenta Willi Krieg., N. vasta Hust. and N. ventraloides Hust. The type materials of these species were examined using both light and scanning electron microscopy and geometric morphometric analysis. The analysis of the valve ultrastructure demonstrated the affiliation of Navicula aggerica, $N$. subbacillum, N. vasta and N. ventraloides to the genus Sellaphora. A Principal Component Analysis based on the shape of the valve outline, allowed us to define the European taxa Sellaphora stroemii, S. ventraloides and S. aggerica as three separated taxa, clearly distinct from the Indonesian diatom Sellaphora subbacillum, comb. nov. Moreover, considering the need of a replacement name for Navicula subcontenta (KRIEGER 1943), already validly published by HuSTEDT in 1942, we propose the new name Navicula petrmarvanii nom. nov. for KRIEGER's species.
\end{abstract}

Key words: biogeography, diatoms, geometric morphometrics, morphological variation, ultrastructure, new combinations, new name

\section{Introduction}

Until ca. 1900, the species belonging to the biraphid diatom genus Sellaphora MereschK. were classified within Navicula BoRY due to their simple boat-shaped valves (BEHNKE et al. 2004). Subsequently, Sellaphora was separated from Navicula by MereschKowsky (1902) who included in this genus all the naviculoid diatoms with an $\mathrm{H}$-shaped plastid containing an invaginated pyrenoid. Initially, this genus was not accepted by Hustedt (1961), but finally the genus Sellaphora was re-established by MANN (1989). Since the early 1980's MANN and his collaborators have been investigating this genus from a morphological and genetic point of view. Morphometric analysis (MANn 2001, MANN et al. 2004) and descriptions of several Sellaphora species were supported by data from molecular systematics (MANN 1999, BEHNKE et al. 2004), sometimes evidencing discrepancies between both classification methods (EvAns et al. 2007, 2008). Investigations were mainly carried out on large Sellaphora species. Indeed, the Sellaphora americana (EHRENB.) D.G. Mann, S. bacillum (Ehrenb.) D.G. Mann, S. laevissima (KÜTz.) D.G. MANN and S. pupula (Kütz.) MereschK. complexes were widely investigated since they are the most commonly 
recorded species belonging to this genus (MANN et al. 2008). These four species were initially placed into the section Bacillares Cleve (Krammer \& Lange-Bertalot 1986) and into the subgenus Bacillum R.M. Patrick (Patrick \& Reimer 1966) within the genus Navicula, and later transferred to the genus Sellaphora by MereschKowsky (1902) and MANN (1989).

This study is focused on the species around Navicula stroemii Hust. 1931, initially considered as part of the section Bacillares. We started our investigation with the study of three populations collected in Italy, Slovakia and Spain, identified as Navicula stroemii sensu KRAMMER \& LANGE-Bertalot 1986 (unpubl. results). The large morphological variability within these populations led us to further investigate the Sellaphora stroemii complex. According to Krammer \& Lange-Bertalot (1986) the $S$. stroemii complex is composed by small species (7.8-24.0 $\mu \mathrm{m}$ length and 3.2-5.1 $\mu \mathrm{m}$ width), characterized by linear valves with slightly convex margins. The shape of the poles ranges from rounded to subcapitate. The striation is generally visible under light microscope, with 23-28 striae in $10 \mu \mathrm{m}$, becoming sparser near the central area. The raphe is linear, usually flanked by parallel furrows, continuous or interrupted near the central area, often discernable under light microscope. The shape of the central area is variable, from almost absent, small and rounded to considerably expanded (bow-tie-shaped). According to literature data, Navicula stroemii seems to tolerate a wide range of environmental conditions, especially concerning dissolved oxygen and humidity; indeed, this species is able to survive both in meromictic lakes (GÜTTINGER \& StRaub 1998) and in aerial conditions (Beyens \& De Bock 1989, Van KerckVoorde et al. 2000). $N$. stroemii is typical of calcareous rivers (KRAMMER \& LANGe-Bertalot 1986, SABATER \& Roca 1992) and has been considered as an endangered species in the German Red List of LANGE-BERTALOT (1996). Recently, KoBAyAsi in MAYAMA et al. (2002) transferred N. stroemii into the genus Sellaphora. Following Krammer \& LANGE-Bertalot (1986), six different species should be considered as taxonomic synonyms of Navicula stroemii Hust. 1931, namely $N$. subbacillum Hust. 1937, $N$. vasta Hust. 1937, N. rivularis Hust. 1942, N. subcontenta Willi KRIEG. 1943, N. ventraloides Hust. 1945, and N. aggerica E. Reichardt 1982. The type materials of Navicula stroemii, $N$. rivularis, $N$. ventraloides and $N$. aggerica were collected in Europe. In particular, the type material of Navicula stroemii was designated by HUSTEDT (1931) from an epilithic sample of Feforvatn, a meromictic lake in Norway. The author indicated in the diagnosis of Navicula stroemii (Strömii) the following dimensions: 10-15 $\mu \mathrm{m}$ length, $3.5-4.5 \mu \mathrm{m}$ width, 24 striae in $10 \mu \mathrm{m}$ at the middle (Hustedt 1931). Navicula rivularis was discovered in a discharge brook ("Abflussbach") in Abisko, Sweden (Hustedt 1942a). Navicula ventraloides was collected in a waterfall of the Plitvice National Park, Croatia (HustedT 1945). Navicula aggerica was found by REICHARDT (1982) in a sample collected on a stone gutter near Weissenburg in Bavaria, Germany. The data concerning the ecological preferences of the type materials are scarce or inexistent.

On the contrary, Navicula subbacillum and also $N$. vasta were collected in the Indonesian Archipelago and described by Hustedt in 1937. Navicula subbacillum was found by HustedT (1937) on a waterfall in a calcareous tufa area within Panjingahan and in a hot spring within Bukit Kili, West Sumatra, being also present in the north of Sumatra. It was described as an evidently aerophilic species from alkaline springs, although some specimens were recorded in Toba lake (North-central Sumatra), in the littoral at 3-5 $\mathrm{m}$ depth; the latter specimens were more densely striated than the aerophilic ones suggesting a probable morphological variability in relation to the environmental features (HustedT 1937). Navicula vasta was found only in Java on the waterfalls of Kali Djumok, Tjurug Tjikundul and Tjurug Dengdeng, and was described as an aerophilic spring-form, with an optimum $\mathrm{pH}$ around 8.0-8.2.

Due to the morphological and biogeographical differences within the Navicula stroemii complex and the lack of a clear and unequivocal iconographyillustrating the species of thiscomplex, we performed a revision of their type materials. Moreover, we supplemented the information provided by traditional taxonomic methodologies by means of a geometric morphometric analysis developed by RoHLF (2004). This method gives an objective and repeatable evaluation of the morphological differences and similarities among closely related taxa, being a useful tool in better delineating accurate boundaries within taxonomic complexes (Potapova \& Hamilton 2007). This study aims $i$ ) to investigate the Sellaphora 
stroemii complex, contributing to the global monograph of the genus Sellaphora, as conceived by Mann et al. (2008); ii) to study Hustedt's and REICHARDT's type materials of the species complex, using both conventional methodologies (LM and SEM observations) and geometric morphometric analysis; iii) to provide a complete description and photographic documentation of the taxa forming the complex and to show their worldwide distribution through the analysis of bibliographic data, and iiii) to compare type materials with three natural populations collected in different rivers of Europe and identified as Navicula stroemii sensu Krammer \& LANGe-Bertalot 1986.

\section{Material and methods}

Navicula stroemii, N. subbacillum, $N$. vasta, N. rivularis and $N$. ventraloides type materials were obtained from the HustedT's Collection in the Alfred Wegener Institute for Polar- and Marine Research, Bremerhaven, Germany. Navicula aggerica type material was provided by Dr. ERWIN REICHARDT, Treuchtlingen, Germany. Unfortunately the type material of Navicula subcontenta WiLLI KRIEG. 1943 could not be found in the Krieger collection in Berlin (Regine Jahn, pers. comm.), so we used KRIEGER's original drawing as interpretative type (KRIEGER 1943, p. 262; fig. 18; in this study Figure 133) to investigate this species.

Six samples from HustedT's and ReichardT's type material collections were examined (listed here according to the original names):

- Navicula stroemii Hust. 1931 (Holotype: slide No. 191/3. Norway. Feforvatn. 1. an Steinen);

- Navicula subbacillum Hust. 1937 (Lectotype designated by SimONSEN (1987): slide No. N12/22. Indonesia. Sumatra. Wasserfall v. Panjingahan. SBK3ab);

- Navicula vasta Hust. 1937 (Holotype: slide No. N8/90. Indonesia. Java. Tengger. Quelle. TG1d);

- Navicula rivularis Hust. 1942 (Holotype: Slide No. N7/33. Sweden. Abisko. 169. Abflussbach. c.);

- Navicula ventraloides Hust. 1945 (Lectotype designated by SimONSEN (1987): slide No. M2/43. Croatia. Plitvicer Seengebiet. 11. Wasserfall);

- Navicula aggerica E. Reichardt 1982 (Type material. No. S61. Germany. Steinerne Rinne near Weissenburg, Bavaria).

All these taxa were examined using both light (LM) and scanning electron (SEM) microscopy, while $N$. rivularis was only observed with LM due to the insufficient number of cells in the sample.

Three populations of the Sellaphora stroemii complex, from Chianocco stream (Piedmont, Italy), Oravica River (Vitanova, Slovakia) and Arba de Biel
River (Zaragoza, Spain), were examined. Live field populations were observed under LM in order to confirm their possible assignment to the genus Sellaphora according to the shape of the plastid. Treated samples were observed using both LM and SEM and compared with the type materials.

For the LM analysis, all samples were cleaned with hot hydrogen peroxide and hydrochloric acid and finally mounted on glass slides with Naphrax ${ }^{\circledR}$. LM observations and morphometric measurements were performed with a Leica DMRX with 100X oil immersion objective, equipped with a Leica DC500 digital camera. For SEM analysis, cleaned samples were dried onto glass coverslips attached to aluminum stubs, sputtered with a $40 \mathrm{~nm}$ gold layer and examined with a Leica Stereoscan 430i operating at $20 \mathrm{kV}$.

Valve shape analysis by means of geometric morphometric methods was performed on 96 individuals photographed from the type materials: 22 images of Navicula stroemii, 23 of $N$. aggerica, 23 of $N$. subbacillum, 17 of $N$. vasta, and 11 of $N$. ventraloides. We excluded $N$. rivularis from the procedure due to the scarcity of cells in the type material. For this analysis, we placed 12 landmarks at the curvature extremes along the valve outline (Fig. 1) and we digitised them using tpsDig2 software (RoHlf 2004). The Cartesian coordinates of all the cells were aligned (translated, rotated and scaled) by the Procrustes generalized orthogonal least-squared superimposition procedure (RohlF \& Slice 1990). On the basis of the resulting normalized landmark coordinates, we performed a multivariate analysis (Principal Component Analysis, PCA) by means of the software Past version 1.78 (HAMmer et al. 2001). Finally, a similarity test (HotelLing's multivariate discriminant test) was performed between the Cartesian coordinates of the $a$ priori defined groups in the PCA using the Euclidean distance measure in order to account for statistically significant differences concerning the shape of the poles and the valve width among the type populations. Despite being aware of the limits of the published records in defining the geographical distribution of

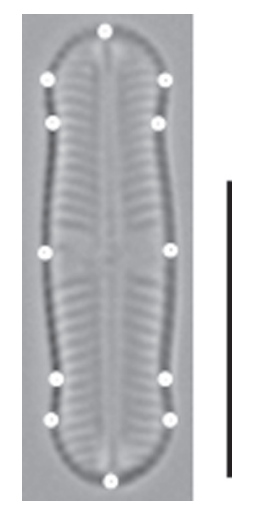

Fig. 1. Position of the 12 landmarks on the valve outline used to perform the geometric morphometric analysis. Scale bar $10 \mu \mathrm{m}$. 

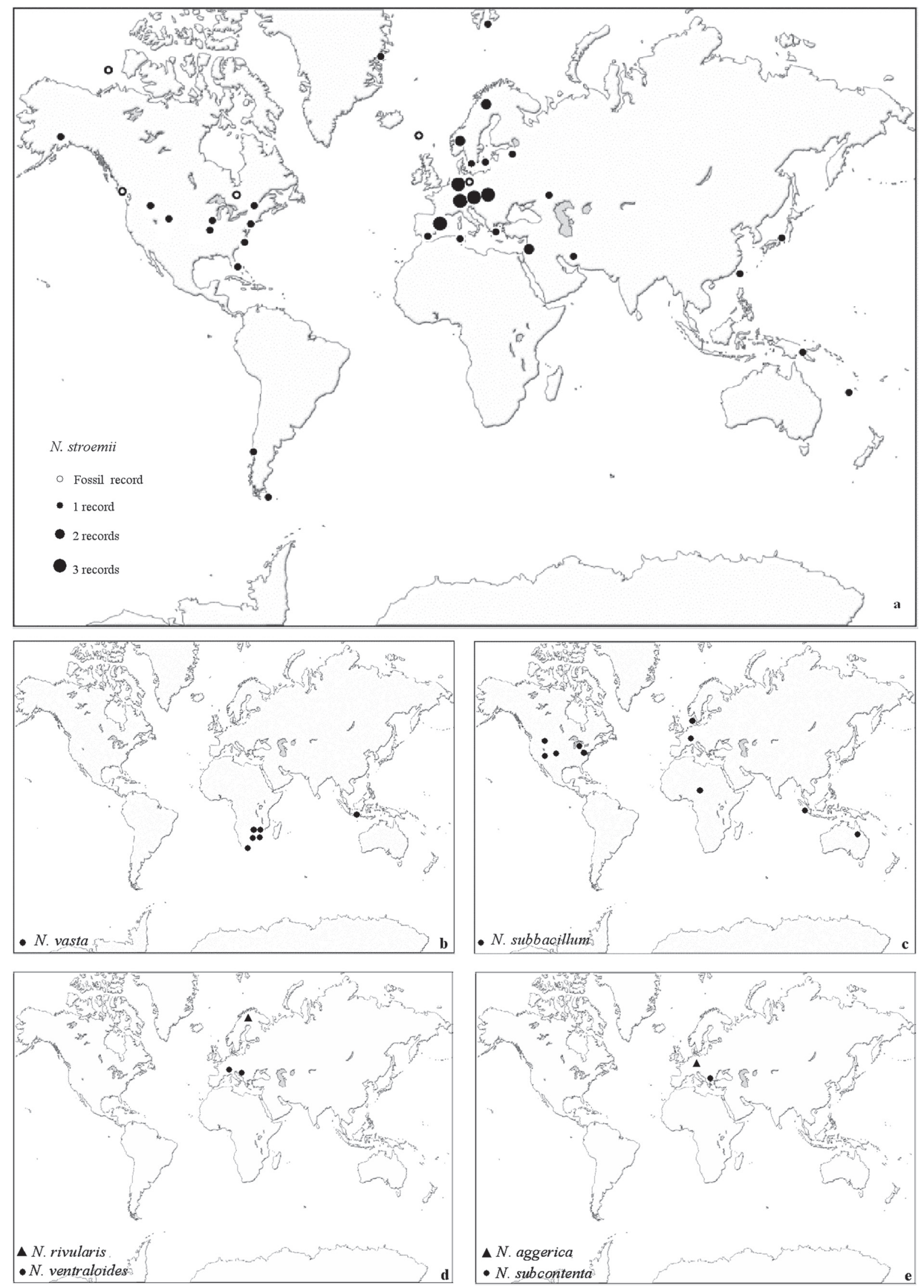

Fig. 2. World distribution, based on literature data, of: (a) Navicula stroemii Hust.; (b) N. vasta Hust.; (c) N. subbacillum Hust.; (d) N. rivularis Hust. and N. ventraloides Hust.; (e) N. aggerica E. Reichardt and N. subcontenta Willi Krieg. 


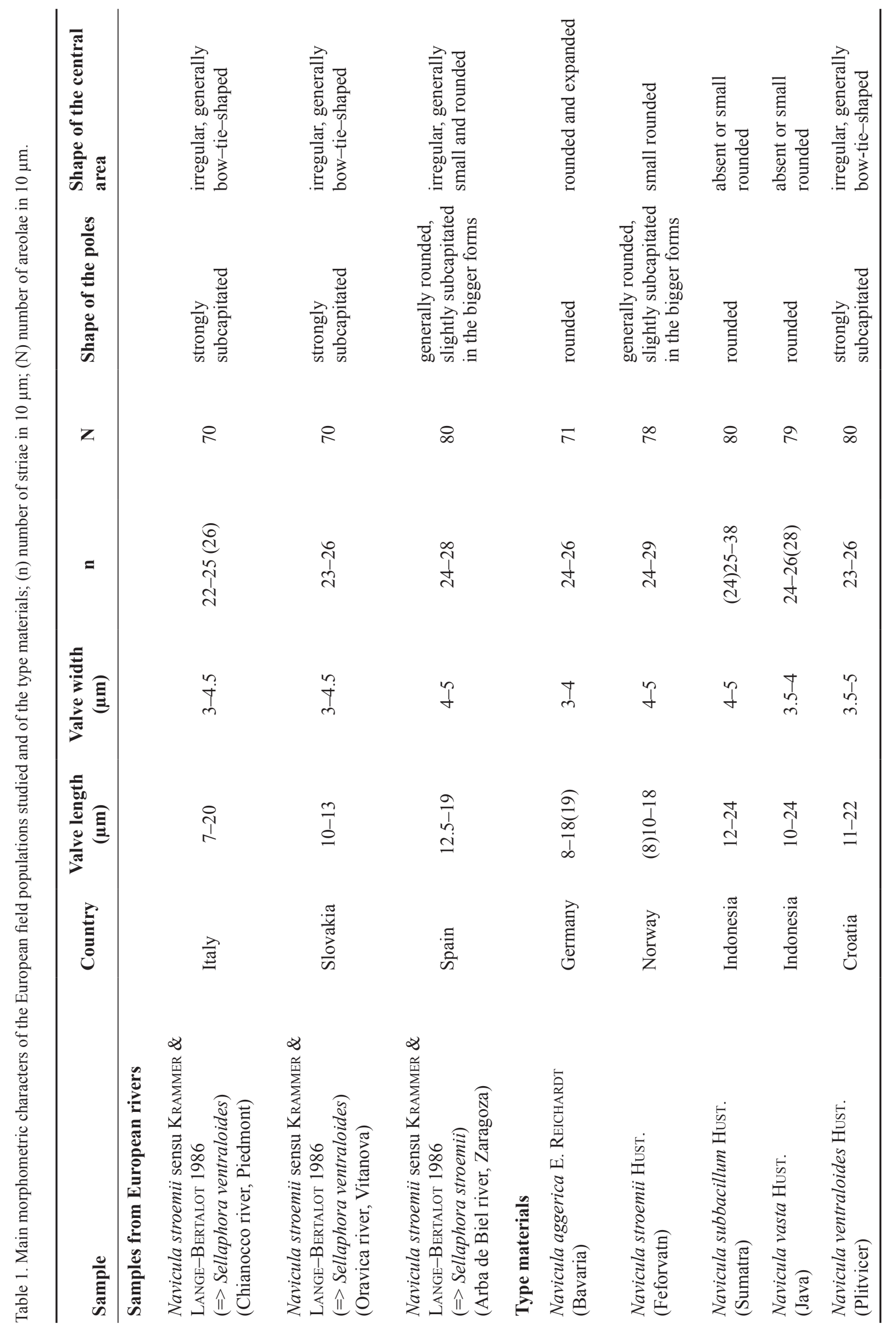


species (MAnN et al. 2008, Blanco \& Ector 2009) we constructed world distribution maps for Navicula stroemii, $N$. vasta, $N$. subbacillum, $N$. rivularis, N.ventraloides, N. aggerica and N. subcontenta (Fig. 2).

\section{Results and discussion}

\section{Analysis of samples from European rivers}

Live material from three populations, identified in previous inventories as Navicula stroemii sensu Krammer \& Lange-Bertalot 1986 and collected in rivers of Italy, Slovakia and Spain was analysed under LM. All three populations showed the typical single $\mathrm{H}$-shaped plastid, characteristic of the genus Sellaphora (Figs 44-45). Beside some common features, such as the variable shape of the central area from small and rounded to large and bow-tie-shaped, LM (Figs 3-53) and SEM (Figs 54-62) analyses highlighted a wide morphological variability in valve outline among these taxa. Specifically, the Italian (Figs 3-22) and Slovak (Figs 23-43) cells are generally strongly subcapitate. On the contrary, the Spanish specimens (Figs 46-53) are never strongly subcapitate, not even the larger individuals. The main morphometric and morphological features of the field populations are summarized in Table S1.

The differences in the shape of the poles led us to hypothesize the presence of two distinct morphs within these field samples. Considering this, we thoroughly investigated the type materials from the Navicula stroemii complex sensu Krammer \& LANGe-Bertalot 1986.

\section{Type material analyses}

LM illustrations of the type populations of Navicula stroemii, $N$. subbacillum, $N$. vasta, $N$. rivularis, $N$. ventraloides, and $N$. aggerica are provided in Figs 63-116. Morphometric features are summarized in Table 1. From LM analysis we can observe that all the examined type populations are variable through the generations. Despite this, it is possible to recognize some common features: the cells are small and linear, with straight raphe delimited by two furrows, generally interrupted near the central area and appearing like two lines under the LM. Conversely, valve outline and shape of the poles, from broadly rounded to strongly subcapitate, represent characters used to discern the type populations.

\section{Geometric morphometric analysis}

In order to detect the differences concerning the shape of the poles and the valve width among the type populations we performed a PCA analysis on the normalized landmark coordinates (Fig. 117). The results indicate presence of significant morphological differences (HotelLing's $\mathrm{T}^{2}$; $\mathrm{p}<$ 0.001 ) within the Sellaphora stroemii complex on the basis of the valve outline: one group including Navicula stroemii and $N$. ventraloides, and a second group with $N$. aggerica, $N$. subbacillum and $N$. vasta. The overlapping area represents extreme cell shapes with peculiar outlines.

\section{Microscopical analysis}

LM and SEM analyses were used to detect the differences between both groups obtained in the PCA plot. By comparing the type populations of Navicula stroemii and $N$. ventraloides, we can observe that they mainly differ in the valve outline. Specifically, the shape of the poles is generally rounded in Sellaphora stroemii and strongly subcapitate in Navicula ventraloides. Considering this, we advance the hypothesis that the strongly subcapitate Italian and Slovak river populations belong to $N$. ventraloides, while the Spanish river population should be identified as Navicula stroemii. Moreover, considering the affiliation of these populations from European rivers to the genus Sellaphora and due to the unambiguous resemblance to the Navicula stroemii and Navicula ventraloides types, we propose to transfer the latter to the genus Sellaphora. Despite of the shape of Navicula rivularis (Figs 76-79) being similar to $N$. ventraloides, we were not able to demonstrate its relationship with this group, due to the scarce number of cells found in HusTEDT's type material.

Analysing the second group provided by the PCA through LM and SEM analysis, we observed no differences between $N$. subbacillum and $N$. vasta along their whole size spectra. Therefore, we propose to synonymize these two taxa under a unique species. On the other hand, it is possible to detect a difference in the shape of the central area between this new complex and $N$. aggerica. In accordance with the idea that species belonging to the genus Navicula sensu stricto have to share morphological features with the generitype N. tripunctata (O. MÜll.) BoRY (COX 1979, Gligora et al. 2009), we propose to transfer $N$. aggerica, $N$. subbacillum and $N$. vasta into a more appropriate genus, since the latter taxa never 


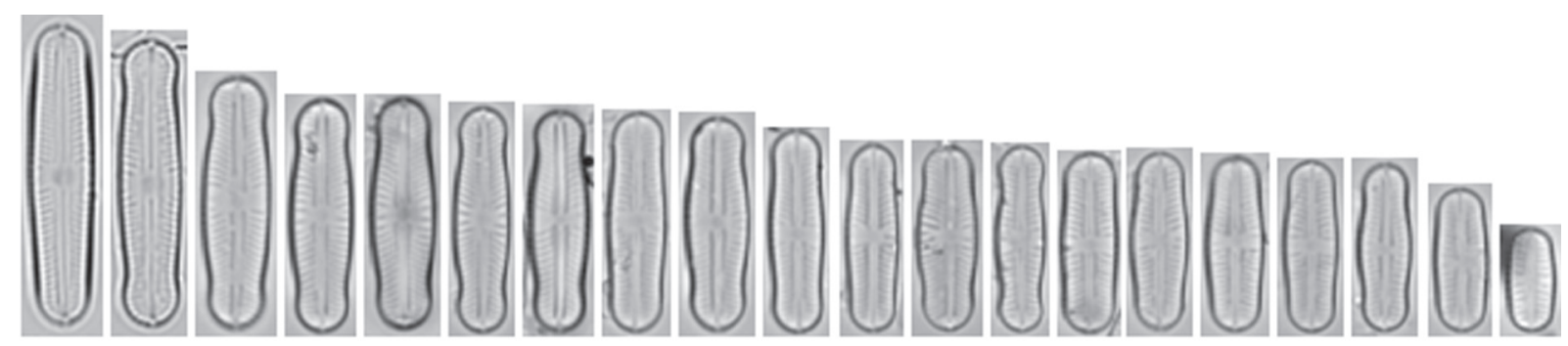

$3-22$

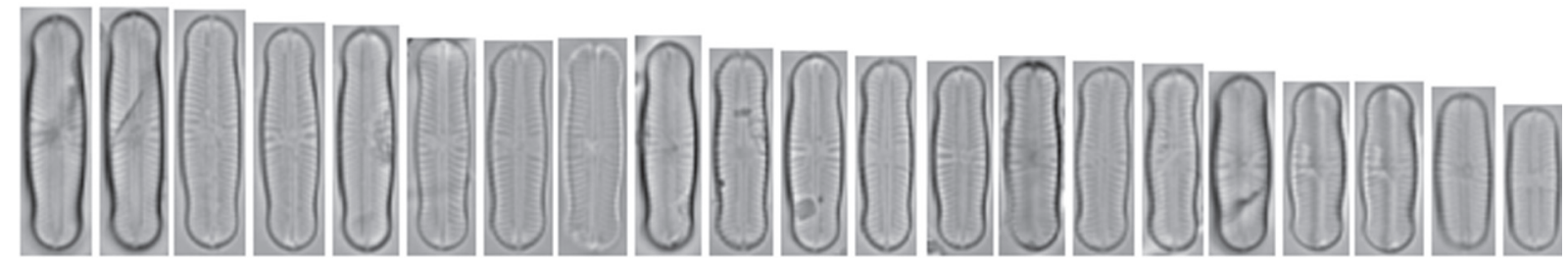

$23-43$

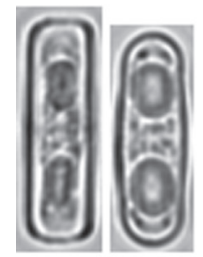

$44-45$

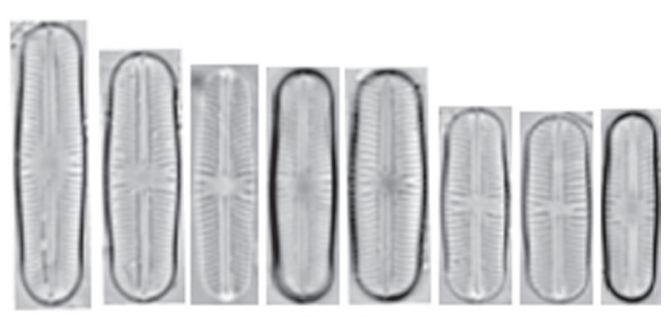

$46-53$

Figs 3-53. LM micrographs of three populations of Navicula stroemii Hust. sensu Krammer \& LANGE-Bertalot 1986 collected in different European rivers: (3-22) population from Chianocco stream, Piedmont, Italy; (23-43) population from Oravica river, Vitanova, Slovakia; $(44,45)$ live material from Chianocco stream, Piedmont, Italy; (46-53) population from Arba de Biel river, Zaragoza, Spain. Scale bar $10 \mu \mathrm{m}$.

presented the apically elongated and linear poroids characterizing the striae of the genus Navicula, but rather rounded areolae. Navicula aggerica, $N$. subbacillum and $N$. vasta never showed pores externally occluded by hymens, thus we excluded their affiliation to the genera Adlafia GERD. Moser et al. 1998, Veigaludwigia LANGE-Bert. et U. Rumrich in Metzeltin \& Lange-Bertalot 2000, or to the recently described Envekadea VAN DE ViJver et al. (Gligora et al. 2009). The extremely radiated and dense striation pattern led us to rule out Cavinula D.G. Mann et Stickle in Round et al. 1990 from the hypothesis. The coarse structure of the areolae forming the striation excluded all those genera close to the former Navicula section Punctatae Cleve (Krammer \& Lange-Bertalot 1986) (i.e. Cosmioneis D.G. Mann et Stickle in Round et al. 1990, Petroneis Stickle et D.G. Mann in Round et al. 1990, Placoneis MereschK. and Luticola D.G. MANN in Round et al. 1990). Fallacia Stickle et D.G. MAnN in Round et al. 1990 was discarded due to the lack of the lateral sterna characterizing the genera (risen from
Navicula section Lyratae Cleve); moreover, the areolae of Navicula aggerica, N. subbacillum and $N$. vasta were never externally occluded by finely porous conopea as in Fallacia (Round et al. 1990). Considering the notable morphological resemblance with Navicula stroemii and $N$. ventraloides we propose to also transfer Navicula aggerica, and N. subbacillum and N. vasta into the genus Sellaphora.

In the following section we provide a short morphological description and photographical documentation for each new combination proposed in the text, based on LM and SEM analyses of the corresponding type material.

\section{Sellaphora stroemii (Hust.) H. KobayasI in MaYama et al. 2002, p. 90}

Basionym: Navicula stroemii Hust. in Archiv für Hydrobiologie, 22: 544, fig. 3 (1931)

\section{Light microscopy (Figs 63-75)}

Valves linear with rounded ends, sometimes slightly subcapitate in the bigger forms. Length 

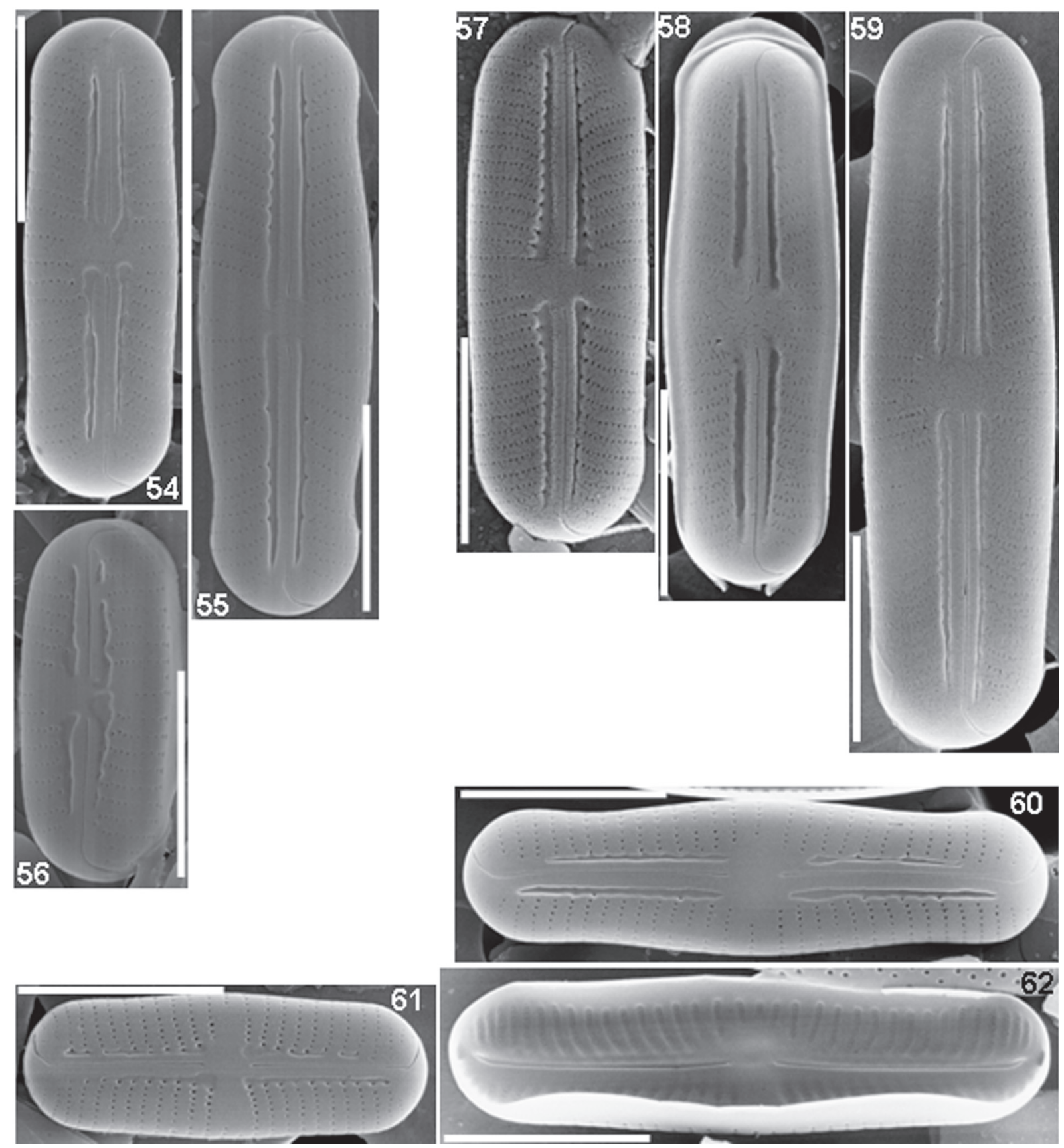

Figs 54-62. SEM micrographs of three populations of Navicula stroemii Hust. sensu Krammer \& LANGE-Bertalot 1986 collected in different European rivers: (54-56) population from Oravica river, Vitanova, Slovakia; external view; (57-59) population from Arba de Biel river, Zaragoza, Spain; external view; (60-62) population from Chianocco stream, Piedmont, Italy: external view (Figs 60,61), internal view (Fig. 62). Scale bars $5 \mu \mathrm{m}$.

(8)10-18 $\mu \mathrm{m}$, width 4-5 $\mu \mathrm{m}$. Raphe filiform, straight, with the external ends bent towards the primary side of the valve. The raphe sternum is flanked by parallel furrows, continuous or interrupted at the level of central area, often visible under LM as longitudinal lines. Narrow axial area often expanded in the middle giving a bow-tie-shaped central area. Striae often visible in $\mathrm{LM}$, radiate, $24-29$ in $10 \mu \mathrm{m}$, becoming sparser and sometimes alternating irregularly, shorter and longer in the central area.

\section{Electron microscopy (Figs 118-120)}

In external view, striae uniseriate, strongly punctuated, each composed by 7-12 irregularly shaped, coarse foramina (c. 78 in $10 \mu \mathrm{m}$ ). In the internal view, the areolae sometimes appear occluded by hymens. Distal raphe ends form a small helictoglossa. Terminal fissures absent. 


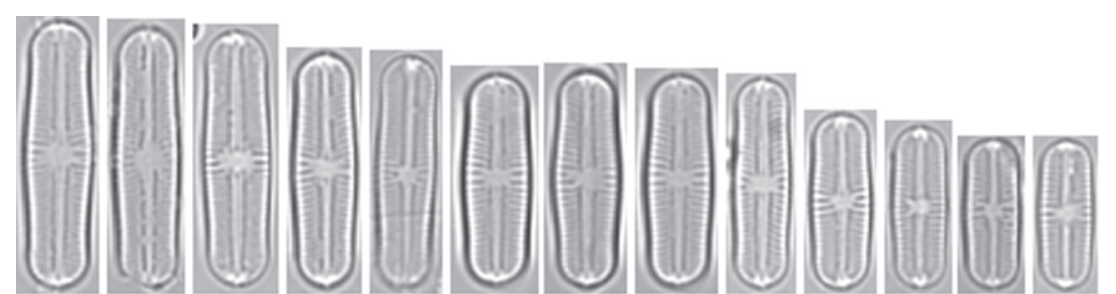

$63-75$

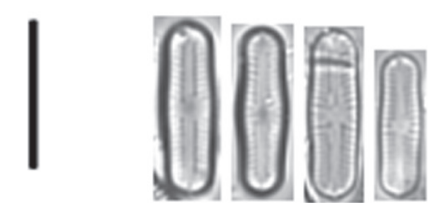

$76-79$

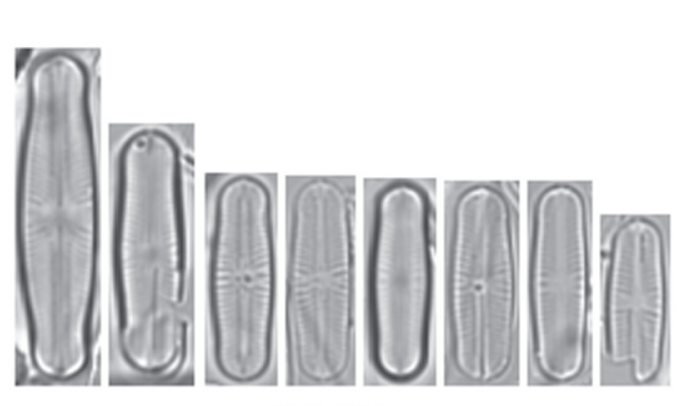

80-87

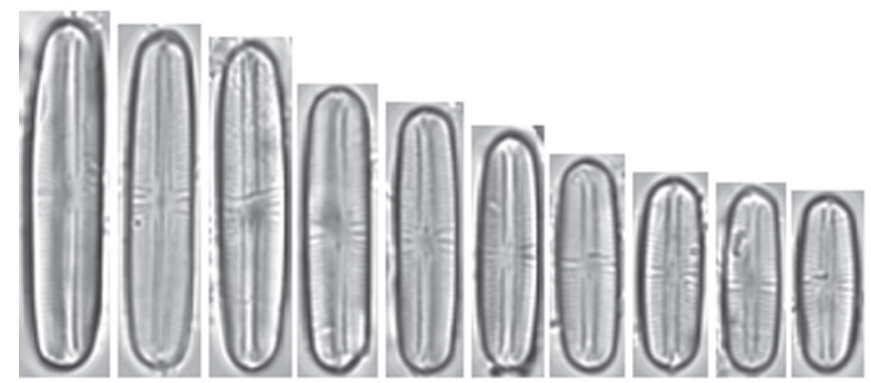

98-107

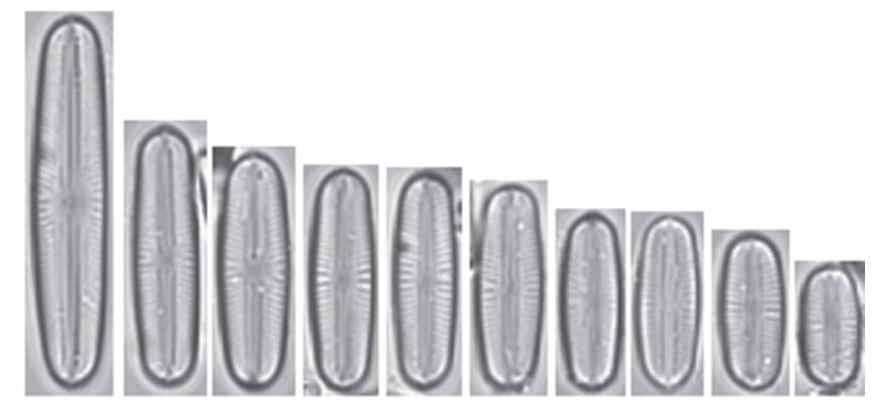

88-97

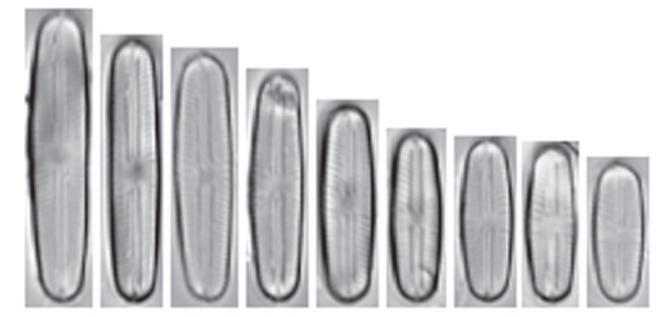

108-116

Figs 63-116. LM micrographs of type materials (species are cited according to their original names): (63-75) Navicula stroemii Hust. 1931; (76-79) N. rivularis Hust. 1942; (80-87) N. ventraloides Hust. 1945; (88-97) N. vasta Hust. 1937; (98-107) N. subbacillum Hust. 1937; (108-116) N. aggerica E. ReIchardt. Scale bar $10 \mu \mathrm{m}$.

\section{Sellaphora ventraloides (Hust.) Falasco et} EcTOR, comb. nov.

Basionym: Navicula ventraloides Hust. in Archiv für Hydrobiologie 40(4): 916, pl. 41, figs 25-28 (1945)

\section{Light microscopy (Figs 80-87)}

Valves linear with strongly subcapitate ends, both in the smallest and in the largest forms. Length 11$22 \mu \mathrm{m}$, width 3.5-5.0 $\mu \mathrm{m}$. Raphe filiform, straight, bent towards the primary side of the valve at the poles. The raphe sternum is flanked by parallel furrows, usually interrupted at the level of central area, often visible under LM as longitudinal lines. Axial area narrow, often expanded in the middle giving a bow-tie-shaped central area. Striae often visible in LM, radiate, $23-26$ in $10 \mu \mathrm{m}$, becoming sparser and sometimes completely absent in the central area.

\section{Electron microscopy (Figs 121-123)}

In the outside view, striae uniseriate slightly punctuated, each composed by 7-12 small foramina (c. 80 in $10 \mu \mathrm{m}$ ). In the internal view sometimes the areolae appear occluded by hymens. Distal raphe ends forming a small helictoglossa, terminal fissures absent.

\section{Sellaphora subbacillum (Hust.) Falasco et} ECTOR, comb. nov. et emend.

Basionym: Navicula subbacillum Hust. in Archiv für Hydrobiologie, Supplement 15(2): 256, pl. 18, figs 3-6 (1937)

Synonym: Navicula vasta Hust. in Archiv für Hydrobiologie, Supplement 15(2): 273, pl. 19, figs 19-21 (1937), syn. nov.

\section{Light microscopy (Figs 98-107)}

Valves rather broadly linear with strictly straight margins and very broadly rounded ends, never 


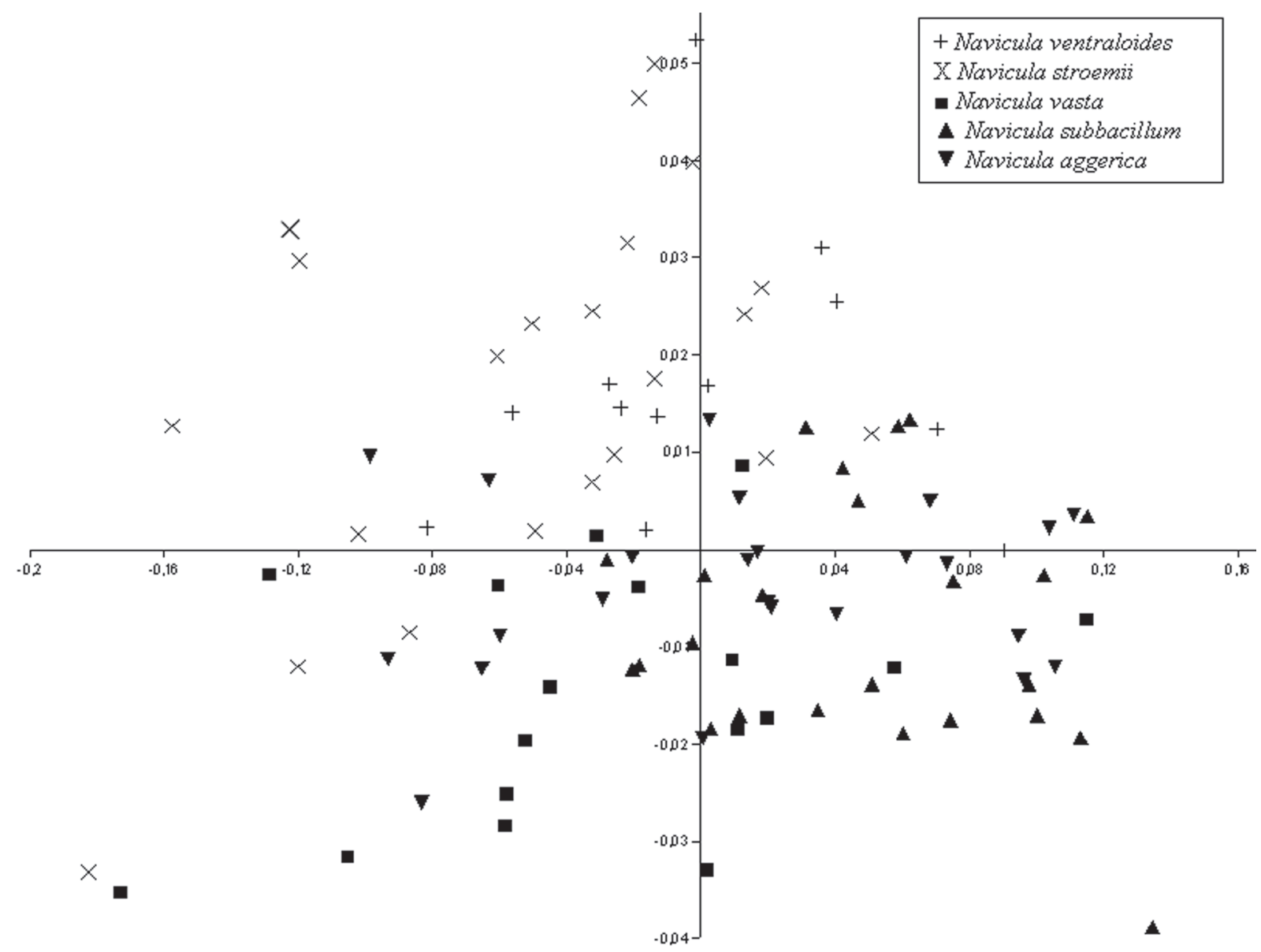

Fig. 117. Principal Component Analysis (PCA) plot of normalized coordinates for the morphological landmarks digitized on LM images for the type populations forming the Navicula (Sellaphora) stroemii complex: + Navicula ventraloides; X N. stroemii; $\mathbf{\square}$. vasta; $\mathbf{\Delta}$ N. subbacillum; $\mathbf{\nabla}$ N. aggerica.

subcapitate. Length 10-24 $\mu \mathrm{m}$, width 3.5-5.0 $\mu \mathrm{m}$. Raphe filiform, straight or slightly undulate, with long external ends bent towards one side of the valve. The parallel apical depressions setting the narrow axial area are irregular, visible under LM, sometimes interrupted at the level of the central area, often not. Central area almost absent or small and rounded. Striae always visible, strongly radiate, $24-28$ in $10 \mu \mathrm{m}$, becoming sparser in the centre.

\section{Electron microscopy (Figs 127-129)}

In external view, striae uniseriate, punctuated (c. 80 in $10 \mu \mathrm{m}$ ), with foramina reaching out the axial depressions. In internal view, the striae appear short, giving rise to a large axial area; the areolae appear usually occluded by circular hymens. Distal raphe ends form a small helictoglossa, terminal fissures absent.
Sellaphora aggerica (E. Reichardt) Falasco et ECTOR, comb. nov.

Basionym: Navicula aggerica E. REICHARDT in Berichte der Bayerischen Botanischen Gesellschaft 53: 101, pl. 1, figs 25-33, pl. 4, figs 9-11 (1982)

\section{Light microscopy (Figs 108-116)}

Valves mostly linear, with rounded poles, never subcapitate. Length 8-18 $\mu \mathrm{m}$, width 3-4 $\mu \mathrm{m}$. Raphe straight, curved towards the same side near the pole (only distinguishable under LM in large specimens), flanked by parallel furrows, usually interrupted at the level of central area. Central area transversally broadened, bow-tie-shaped or rounded, sometimes unevenly developed to the border. Transapical striae consistently radial, 24-26 (mainly 25) in $10 \mu \mathrm{m}$.

\section{Electron microscopy (Figs 130-132)}

In the outside view, striae punctuated, c. 71 puncta in $10 \mu \mathrm{m} ; 1-3$ strongly shortened striae belong to the central area. In internal view, the striae appear short in the centre, defining a large central 

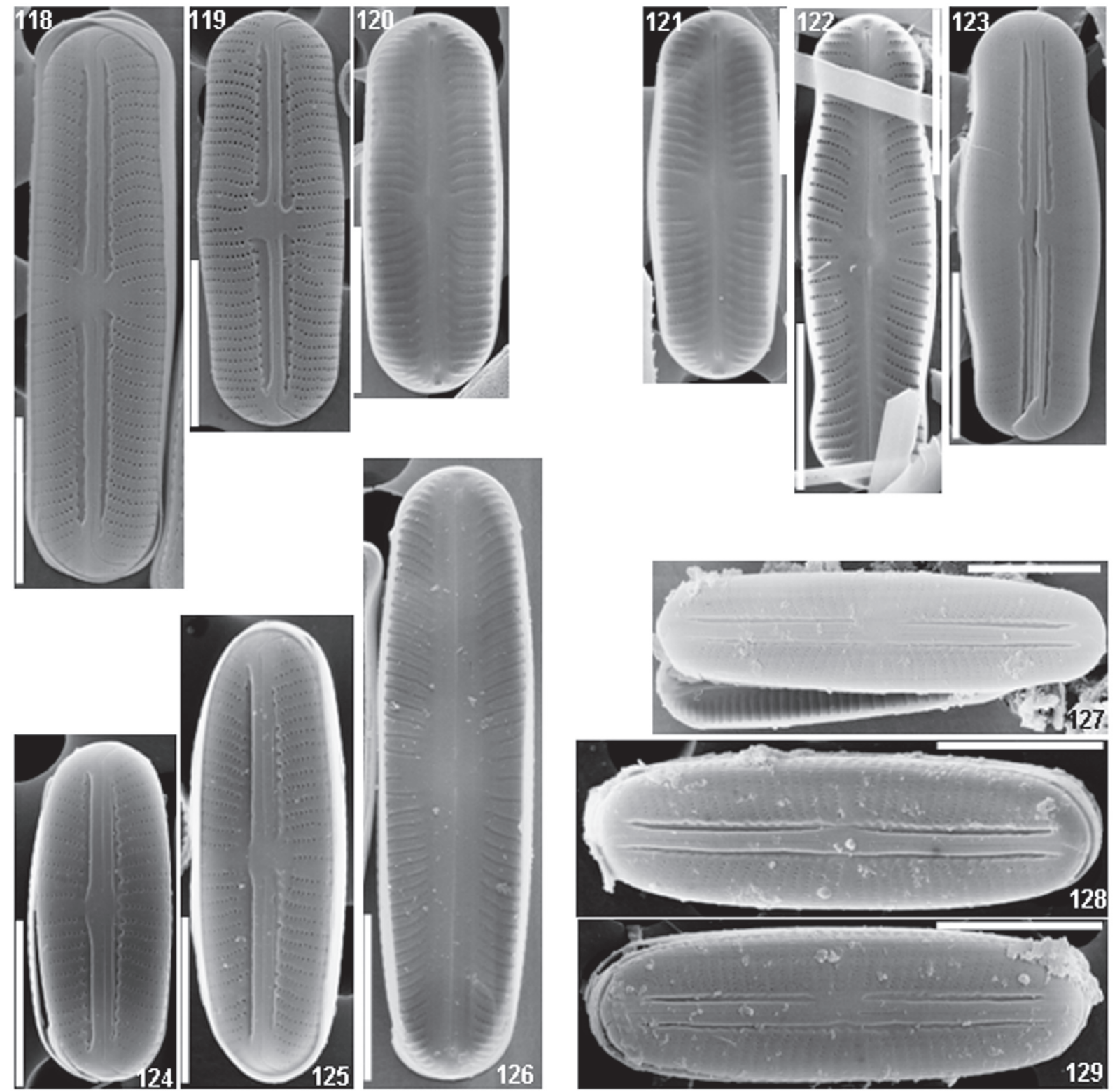

Fig. 118-129. SEM micrographs of Navicula stroemii Hust., N. ventraloides Hust., N. vasta Hust. and N. subbacillum Hust. type materials: (118-120) type material of $N$. stroemii, external view (118-119), internal view (120); (121-123) type material of $N$. ventraloides, internal view (121-122), external view (123); (124-126) type material of $N$. vasta, external view (124-125), internal view (126); (127-129) type material of $N$. subbacillum, external view. Scale bars $5 \mu \mathrm{m}$.

area; the areolae appear usually occluded by circular hymens. Distal raphe ends form a small helictoglossa, terminal fissures absent.

\section{Navicula petrmarvanii Falasco et Ector, nom.} nov.

Basionym: Navicula subcontenta WiLLI KRIEG., Berichte der Deutschen Botanischen Gesellschaft 61(5): 262, fig. 18 (1943).

Non Navicula subcontenta Hust., Internationale Revue der gesamten Hydrobiologie und Hydrographie 42 (1/3): 58, fig. 105 (1942).

Type locality: Mount Athos, Greece (according to KRIEGER 1943).
Etymology: The chosen replacement epithet is dedicated to Dr. Petr Marvan (Academy of Sciences of the Czech Republic), acknowledging his contribution to diatom science.

KRIEGER's unique drawing (Figure 133 in this study) shows a diatom with strong morphological affinities with the $S$. stroemii group. According to KRIEGER's description, Navicula subcontenta is a small species with elliptic cells, slightly inflated in the centre and at the ends. The axial area is very narrow, the central area is elliptic. The central striae are very variable in length, less dense and thicker (about 20 in $10 \mu \mathrm{m}$ ) than those at the 


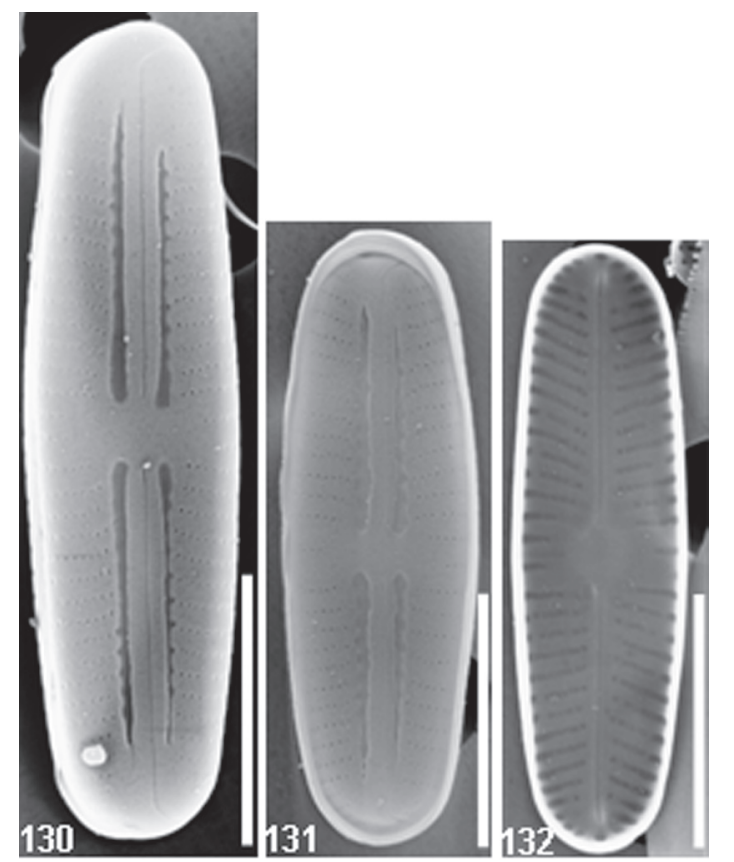

Figs 130-132. SEM micrographs of Navicula aggerica E. REICHARDT type material: external view (130-131), internal view (132). Scale bars $5 \mu \mathrm{m}$

ends $(28$ in $10 \mu \mathrm{m})$. The striae along the cell are divergent, slightly curved. Cell length 14-19 $\mu \mathrm{m}$, width $4 \mu \mathrm{m}$. N. subcontenta can be distinguished from similar species by variable length and lower density of central striae. The binomen Navicula subcontenta had already been validly published by Hustedt (1942b) for a diatom found in Sulawesi (Indonesia), therefore KRIEGER's taxon became an illegitimate later homonym and a replacement name is needed in accordance to the rules of botanical nomenclature. Further investigations of this taxon (after its eventual neotypification, if necessary) are necessary to evaluate its possible transfer to the genus Sellaphora.

\section{Final taxonomical remarks}

On the basis of this re-evaluation of the Sellaphora stroemii species complex, the populations from European rivers, initially identified by the authors as Navicula stroemii sensu KRAMMER \& LANGEBertalot 1986, should thus be referred to $S$. ventraloides for the Italian and Slovak populations, and S. stroemii for the Spanish populations.

In re-defining the Sellaphora stroemii complex, we propose new combinations that appeared coherent to the morphological features and the biogeographical distribution of the species. Sellaphora stroemii and $S$. ventraloides are morphologically well separated from Sellaphora aggerica and S. subbacillum on the basis of the

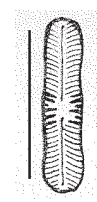

Fig. 133. Drawing of Navicula subcontenta WiLli KrIEG. (according to KRIEGER 1943, Berichte der Deutschen Botanischen Gesellschaft 61(5): 262, fig. 18). Scale bar 10 $\mu \mathrm{m}$.

general valve outline and should be considered as distinct species with regard to the shape of the poles, confirming the hypothesis proposed by Hustedt $(1931,1945)$. The splitting of the complex is confirmed by the autoecology and the distributional range of the species. Navicula stroemii and $N$. ventraloides were described from Europe, respectively in Abisko (Sweden) and Plitvicer (Croatia), while N. subbacillum and N. vasta were sampled in Indonesia, in Sumatra and Java, respectively.

The strong morphological similarity of $N$. subbacillum and $N$. vasta leads us to consider them as taxonomic synonyms under the unique name Sellaphora subbacillum (Hust.) Falasco et EcTOR. Even though Sellaphora aggerica could be easily confused with the species described in this paper, it is possible to define the shape of the central area as a distinctive character. $S$. aggerica shows a constant, rounded central area, with 1-3 strongly shortened striae, whilst S. subbacillum shows a smaller, rounded central area with a sparser striation in comparison to the transapical one. Even though the central area can sometimes appear big in the larger specimens of S. subbacillum, the striae are never as short and scarce as in $S$. aggerica.

\section{Conclusions}

In our research, we followed the "Waltonian species concept", with reference to the review of MANN (1999) on the species concept in diatoms, trying to merge the very limited knowledge on Sellaphora stroemii complex, which mainly concerned morphology and geographical distribution.

The application of the geometric morphological approach gave a statistical evidence to the identification of morphological groups allowing to distinguish several taxa within the species complex of Navicula stroemii sensu 
Krammer \& Lange-Bertalot 1986. Even though it represents an important tool for morphological investigations, computer-assisted valve shape analysis cannot replace at this stage the traditional taxonomic studies with LM and SEM, thus it should be considered only as a complementary tool. Indeed, only the examination of the type materials with LM and SEM allows a deeper knowledge of the groups derived from the PCA analysis. As already stated by MANN \& DROOP (1996), "a more fine grain taxonomy" will enhance the assessment of biodiversity, distribution and ecological requirements of diatoms with consequences on biological survey and paleoecological reconstruction. This approach would also lead to a better definition of endemism, endangered species and local extinction processes, to be considered for conservation purposes.

The LM and SEM analyses of the Italian, Slovak and Spanish populations identified previously by the authors as Navicula stroemii sensu Krammer \& LANGE-Bertalot 1986 highlight the uncertainty of the records published in literature (MANN et al. 2008). Considering the results of this research, Sellaphora stroemii and $S$. ventraloides could be both commonly widespread in Europe and were often confused. Even though the taxonomic features used to discriminate these two taxa are well defined, the identification of $S$. stroemii and $S$. ventraloides is possible only through the analysis of large populations showing the complete life cycle. Indeed, especially in small specimens, the decrease of the valve through the generations leads to the oversimplification of the outline, and consequently, the shape of the poles tends to be similar in both taxa.

Further investigations are necessary to better define the autecology and the distribution of these species toward the implementation of the diatom indices for the evaluation of river water quality in Europe.

\section{Acknowledgements}

We would like to express our gratitude to Dr. Richard Crawford and Mrs. Friedel Hinz (Friedrich Hustedt Diatom Collection, Alfred Wegener Institute for Polarand Marine Research) for valuable help with Hustedt's samples and the references used for the preparation of the manuscript, to Dr. Reichardt for providing the type materiel of Navicula aggerica. We are grateful to Christophe Bouillon for his technical SEM assistance and to Damien Marion for the help with the translations from German.

\section{References}

Behnke, A., Friedl, T., Chepurnov, V.A. \& Mann, D.G. (2004): Reproductive compatibility and rDNA sequence analyses in the Sellaphora pupula species complex (Bacillariophyta). - J. Phycol. 40: 193-208.

Beyens, L. \& De Bock, P. (1989): Moss dwelling diatom assemblages from Edgeøya (Svalbard). - Polar Biol. 9: 423-430.

Blanco, S. \& Ector, L. (2009): Distribution, ecology and nuisance effects of the freshwater invasive diatom Didymosphenia geminata (Lyngbye) M. Schmidt: a literature review. - Nova Hedwigia 88: 347-422.

Cox, E.J. (1979): Taxonomic studies on the diatom genus Navicula Bory. The typification of the genus. - Bacillaria 2: 137-153.

Evans, K.M., Wortley, A.H. \& Mann, D.G. (2007): An assessment of potential diatom "barcode" genes (cox1, rbcL, 18S and ITS rDNA) and their effectiveness in determining relationships in Sellaphora (Bacillariophyta). - Protist 158: 349-364.

Evans, K.M., Wortley, A.H., Simpson, G.E., Chepurnov, V.A. \& Mann, D.G. (2008): A molecular systematic approach to explore diversity within the Sellaphora pupula species complex (Bacillariophyta). - J. Phycol. 44: 215-231.

Gligora, M., Kralj, K., Plenković-Moraj, A., Hinz, F., Acs, E., Grigorszky, I., Cocquyt, C. \& VAN DE VIJVER, B. (2009): Observations on the diatom Navicula hedinii Hustedt (Bacillariophyceae) and its transfer to a new genus Envekadea Van de Vijver et al. gen. nov. - Eur. J. Phycol. 44: 123-138.

Güttinger, W. \& Straub, F. (1998): Diatoms of Lake Cadagno. - In: Peduzzi, R., Bachofen, R. \& Tonolla, M. (eds): Lake Cadagno: a meromictic Alpine lake. - Doc. Ist. Ital. Idrobiol. 63: 5764.

Hammer, Ø., Harper, D.A.T. \& Ryan, P.D. (2001): PAST: Paleontological Statistics Software Package for Education and Data Analysis. Palaeont. Electr. 4: 1-9.

Hustedt, F. (1931): Diatomeen aus dem Feforvatn in Norwegen. - Arch. Hydrobiol. 22: 537-545.

Hustedt, F. (1937): Systematische und ökologische Untersuchungen über die Diatomeen-Flora von Java, Bali und Sumatra nach dem Material der Deutschen Limnologischen Sunda-Expedition. "Tropische Binnengewässer, Band VII". - Arch. Hydrobiol. Suppl. 15: 187-295.

Hustedt, F. (1942a): Diatomeen aus der Umgebung von Abisko in Schwedisch-Lappland. - Arch. Hydrobiol. 39: 87-174.

Hustedt, F. (1942b): Süßwasser-Diatomeen des 
indomalayischen Archipels und der HawaiiInseln. - Int. Rev. Gesamten Hydrobiol. Hydrogr. 42: 1-252.

Hustedt, F. (1945): Diatomeen aus Seen und Quellgebieten der Balkan-Halbinsel. - Arch. Hydrobiol. 40: 867-973.

Hustedt, F. (1961): Die Kieselalgen Deutschlands, Österreichs und der Schweiz unter Berücksichtigung der übrigen Länder Europas sowie der angrenzenden Meeresgebiete. - In: RABENHORST, L. (ed.): Kryptogamenflora von Deutschland, Österreich und der Schweiz 7/1. - 160 pp., Akademische Verlagsgesellschaft, Leipzig.

Krammer, K. \& LAnge-Bertalot, H. (1986): Bacillariophyceae, 1. Teil: Naviculaceae. - In: Ettl, H., Gerloff, J., Heynig, H. \& Mollenhauer, D. (eds): Süsswasserflora von Mitteleuropa, Vol. 2 (1). - 876 pp., G. Fischer Verlag, Stuttgart \& New York.

KRIEGER, W. (1943): Süsswasseralgen aus Griechenland. - Ber. Deutsch. Bot. Ges. 61: 250-270.

Lange-Bertalot, H. (1996): Rote Liste der limnischen Kieselalgen (Bacillariophyceae) Deutschlands. - Schr.-R. f. Vegetationskde. 28: 633-677.

Mann, D.G. (1989): The diatom genus Sellaphora: separation from Navicula. - Br. Phycol. J. 24: $1-20$.

ManN, D.G. (1999): The species concept in diatoms (Phycological Reviews 18). - Phycologia 38: 437-495.

Mann, D.G. (2001): The systematics of the Sellaphora pupula complex: typification of $S$. pupula.In: JAhn, R., Kociolek, J.P., Witkowski, A. \& COMPÈRe, P. (eds): Lange-Bertalot-Festschrift. Studies on diatoms, dedicated to Prof. Dr. Dr. h. c. Horst Lange-Bertalot on the occasion of his 65th birthday. - pp. 225-241, A. R. G. Gantner, Ruggell, Liechtenstein.

ManN, D.G. \& Droop, S.J.M. (1996): Biodiversity, biogeography and conservation of diatoms. Hydrobiologia 336: 19-32.

Mann, D.G., McDonald, S.M., Bayer, M.M., Droop, S.J.M., Chepurnov, V.A., Loke, R.E., Ciobanu, A. \& DU Buf, J.M.H. (2004): Morphometric analysis, ultrastructure and mating data provide evidence for five new species of Sellaphora (Bacillariophyceae). - Phycologia 43: 459482.

Mann, D.G., Thomas, S.J. \& Evans, K.M. (2008): Revision of the diatom genus Sellaphora: a first account of the larger species in the British Isles. - Fottea 8: 15-78.

Mayama, S., Idei, M., Osada, K. \& Nagumo, T. (2002): Nomenclatural changes for 20 diatom taxa occurring in Japan. - Diatom 18: 89-91.

Mereschkowsky, C. (1902): On Sellaphora, a new genus of diatoms. - Ann. Mag. Nat. Hist., ser.
7, 9: 185-195.

Patrick, R. \& Reimer, C.W. (1966): The Diatoms of the United States, exclusive of Alaska and Hawaii. Vol. 1: Fragilariaceae, Eunotiaceae, Achnanthaceae, Naviculaceae. - Monogr. Acad. Nat. Sci. Philadelphia 13: 1-688.

Potapova, M. \& Hamilton, P.B. (2007): Morphological and ecological variation within the Achnanthidium minutissimum (Bacillariophyceae) species complex. - J. Phycol. 43: 561-575.

REICHARDT, E. (1982): Die Diatomeenflora der „Steinernen Rinnen“ in Mittelfranken. - Ber. Bayer. Bot. Ges. 53: 97-112.

Rohlf, F.J. (2004): TpsDig, digitize landmarks and outlines, version 2.0. - Department of Ecology and Evolution, State University of New York at Stony Brook. http://life.bio.sunysb.edu/morph/

Rohlf, F.J. \& Slice, D.E. (1990): Extensions of the Procrustes method for the optimal superimposition of landmarks. - Syst. Zool. 39: 40-59.

Round, F.E., Crawford, R.M. \& Mann, D.G. (1990): The diatoms. Biology and morphology of the genera. - 747 pp., Cambridge University Press, Cambridge.

Sabater, S. \& Roca, J.R. (1992): Ecological and biogeographical aspects of diatom distribution in Pyrenean springs. - Br. Phycol. J. 27: 203213.

Simonsen, R. (1987): Atlas and catalogue of the diatom types of Friedrich Hustedt. 3 vols. - J. Cramer, Berlin \& Stuttgart.

Van Kerckvoorde, A., Trappeniers, K., Nijs, I. \& Beyens, L. (2000): Terrestrial soil diatom assemblages from different vegetation types in Zackenberg (Northeast Greenland). - Polar Biol. 23: 392-400.

(C) Czech Phycological Society

Received April 30, 2009

Accepted July 2, 2009 